\title{
Article \\ Let-7i Reduces Aggressive Phenotype and Induces BRCAness in Ovarian Cancer Cells
}

\author{
Evgeny Chirshev ${ }^{1,2}{ }^{1}$, Tise Suzuki ${ }^{1}$, Hanmin Wang ${ }^{1}\left(\mathbb{D}\right.$, Anthony Nguyen ${ }^{1}$, Nozomi Hojo ${ }^{1,+}{ }^{+}$ \\ Linda Sanderman ${ }^{1,3}$, Saied Mirshahidi ${ }^{4}{ }^{\mathbb{D}}$, Yevgeniya J. Ioffe ${ }^{5}$ and Juli J. Unternaehrer $1,6,7, * \mathbb{C}$
}

1 Department of Basic Sciences, Division of Biochemistry, Loma Linda University, Loma Linda, CA 92354, USA; echirshev@students.llu.edu (E.C.); tsuzuki@students.llu.edu (T.S.); hwang1@students.llu.edu (H.W.); anthony_nguyen1994@yahoo.com (A.N.); nozomi.hojo@riken.jp (N.H.); Linda.Sanderman@csusb.edu (L.S.)

2 Department of Pathology and Human Anatomy, Loma Linda University School of Medicine, Loma Linda, CA 92354, USA

3 Biology Department, California State University San Bernardino, San Bernardino, CA 92407, USA

4 Biospecimen Laboratory, Loma Linda University Cancer Center, Department of Basic Sciences, Division of Microbiology \& Molecular Genetics, Loma Linda University, Loma Linda, CA 92354, USA; smirshahidi@llu.edu

5 Department of Gynecology and Obstetrics, Division of Gynecologic Oncology, Loma Linda University Medical Center, Loma Linda, CA 92354, USA; YIoffe@llu.edu

6 Department of Gynecology and Obstetrics, Loma Linda University, Loma Linda, CA 92354, USA

7 Center for Health Disparities and Molecular Medicine, Loma Linda University, Loma Linda, CA 92354, USA

* Correspondence: junternaehrer@llu.edu

† Present address: Laboratory for Prediction of Cell Systems Dynamics, RIKEN, Osaka 565-0874, Japan.

Citation: Chirshev, E.; Suzuki, T.; Wang, H.; Nguyen, A.; Hojo, N.; Sanderman, L.; Mirshahidi, S.; Ioffe, Y.J.; Unternaehrer, J.J. Let-7i Reduces Aggressive Phenotype and Induces BRCAness in Ovarian Cancer Cells. Cancers 2021, 13, 4617. https:// doi.org/10.3390/cancers13184617

Academic Editor: Francesca Orso

Received: 2 July 2021

Accepted: 9 September 2021

Published: 15 September 2021

Publisher's Note: MDPI stays neutral with regard to jurisdictional claims in published maps and institutional affiliations.

Copyright: (C) 2021 by the authors. Licensee MDPI, Basel, Switzerland. This article is an open access article distributed under the terms and conditions of the Creative Commons Attribution (CC BY) license (https:// creativecommons.org/licenses/by/ $4.0 /)$.
Simple Summary: Ovarian cancer has a dismal prognosis and innovative treatment options are necessary to improve survival. Because the microRNA let-7 is often lost in this and other cancers, and its loss is associated with poor prognosis, we focused on therapeutic strategies to replace it. We report that let-7 overexpression in patient-derived cells resulted in a loss of aggressiveness: inhibition of migration and invasion (associated with metastasis), repression of cancer stem cell attributes (necessary for tumor maintenance and recurrence), and promotion of cell death (required for sensitivity to chemotherapy drugs). Further, cells in which let-7 is overexpressed were more sensitive to PARP inhibitors, even in patients who otherwise could not benefit from these drugs. We show that let-7 reduces the expression of several genes that may contribute to these effects. These actions of let-7 add to the rationale for use of this miRNA as a treatment for selected ovarian cancer patients.

Abstract: High-grade serous carcinoma of the ovary is a deadly gynecological cancer with poor long-term survival. Dysregulation of microRNAs has been shown to contribute to the formation of cancer stem cells (CSCs), an important part of oncogenesis and tumor progression. The let-7 family of microRNAs has previously been shown to regulate stemness and has tumor suppressive actions in a variety of cancers, including ovarian. Here, we demonstrate tumor suppressor actions of let-7i: repression of cancer cell stemness, inhibition of migration and invasion, and promotion of apoptosis, features important for cancer progression, relapse, and metastasis. Let-7i over-expression results in increased sensitivity to the PARP inhibitor olaparib in samples without BRCA mutations, consistent with induction of BRCAness phenotype. We also show that let-7i inhibits the expression of several factors involved in the homologous recombination repair (HRR) pathway, providing potential mechanisms by which the BRCAness phenotype could be induced. These actions of let-7i add to the rationale for use of this miRNA as a treatment for ovarian cancer patients, including those without mutations in the HRR pathway.

Keywords: ovarian cancer; miRNA let-7; cancer stem cells; chemoresistance; BRCAness 


\section{Introduction}

Ovarian cancer is the second most common gynecological malignancy in the USA, with $90 \%$ of cancers being epithelial ovarian cancers [1,2]. Most cases of epithelial ovarian cancer are of high-grade serous ovarian carcinoma (HGSOC) with a long-term survival rate of $30 \%$. The majority ( $85 \%$ ) of ovarian cancer patients respond well to initial therapy; however, about $75 \%$ relapse, and this results in poor prognosis and survival [3,4]. At least in part, tumor recurrence/progression after initial therapy is due to the existence of a population of cancer stem-like cells within the tumor present at the inception of treatment. Cancer stem cells (CSCs) are also partially responsible for the maintenance and growth of tumors [5].

The first-line treatment of ovarian cancer involves primary surgical debulking treatment followed by six to eight cycles of combination chemotherapy, typically of platinumbased and taxane agents, sometimes with the addition of VEGF inhibitor bevacizumab [6]. If upfront debulking surgery is not undertaken, the protocol consists of neoadjuvant combination of typically platinum/taxane agents, followed by interval debulking surgery and additional chemotherapy administration. While initially effective, the majority of patients develop recurrence at the rate of 60-85\% [7]. Grossly visible residual disease following debulking surgery is a negative predictor for survival, among other factors, such as patient's age, tumor grade, and pre-surgical tumor burden $[3,8,9]$.

Because chemotherapy drugs cause DNA damage, it is therapeutically desirable to thwart DNA repair mechanisms. The homologous recombination repair (HRR) mechanism of DNA utilizes the undamaged copy of the gene as a template to repair the damaged DNA copy [10]. Poly-ADP ribose polymerase inhibitors (PARPi) have been demonstrated to be an effective targeted therapy, particularly in patients with homologous recombination deficiency (HRD), acquired either as a germline mutation carrier status or as somatic mutations, i.e., in the tumor itself. One of the causes of HRD is inactivation mutations in $B R C A 1 / 2$ genes, either germline or somatic. PARPi suppress the alternative nuclear DNA repair pathway. HRD cells are unable to repair using homologous recombination (HR), and cell lethality is induced [11]. Apart from mutations in BRCA1/2 genes, other defects in HRR induce sensitivity to PARPi. This phenotype is termed as BRCAness [10]. While the patients with an intact HRR pathway are candidates for PARPis, their progression-free survival and response rates are less favorable than those seen in patients with $\mathrm{HRD}$, when treated in the same clinical circumstances [12-15]. In patients with BRCA mutations treated with the PARPi olaparib in maintenance setting for platinum-sensitive ovarian cancer after at least two lines of platinum-based chemotherapy, SOLO2 trials demonstrated an advantage in overall survival of 13 months [16]. Inducing BRCAness phenotype in patients without $B R C A 1 / 2$ mutations can be an effective solution to improve progression-free survival, response to targeted therapy, and possibly even overall survival.

In the modern era, molecular profiling of ovarian cancers has become widely utilized both in the upfront and recurrent treatment settings, with the goal of utilization of targeted therapy. PARPi have become the quintessential compound illustrating the utility of germline and somatic tumor testing. These agents are utilized both as maintenance treatment, sometimes in combination with bevacizumab, and as monotherapy in heavily pretreated recurrent disease $[17,18]$. PARPi have also been widely studied in clinical trials in combination with VEGF inhibitors, immunotherapy, and other targeted agents, in particular cediranib, a VEGF receptor and PDGF tyrosine kinase inhibitor [19].

MicroRNAs (miRNA) are small, 22 nucleotide, non-coding RNAs that regulate gene expression post-transcriptionally by binding the $3^{\prime}$ UTR of mRNA targets [20]. MiRNAs are dysregulated in HGSOC, which affects response to chemotherapy-induced apoptosis [21]. Let-7 (lethal-7) miRNA was first discovered in C. elegans as a heterochronic RNA regulating the transition from L4 into the adult worm [22]. Let-7 regulates stem cell differentiation, as demonstrated by the failure of mutant worms to transition into adults, while overexpression causes premature development [23]. Let-7 is essential to maintain somatic cells in the differentiated state. This miRNA must be repressed for somatic cell reprogramming to 
pluripotency [24-26]. It is repressed in many types of cancer, including ovarian, associated with an increase in stemness and poor prognosis [27-29]. While the regulation of let-7 is incompletely understood, transcriptional, post-transcriptional, and epigenetic regulation are known to occur [30]. Factors that decrease levels of let-7 have also been shown to increase the stemness, invasiveness, and chemoresistance of cancer cells [31-33]. In our previous work, we demonstrated that patient-derived (PD) samples with low levels of let-7 correlate with increased self-renewal, pluripotency, and tumor burden [34]. Thus, therapeutically replacing let-7 could be a strategy to combat cancer cell aggressiveness.

Since let-7 is a known tumor suppressor microRNA, its up-regulation results in repression of a variety of its target oncogenes. Among them, LIN28A and HMGA2 have been implicated in cancer initiation, progression, and chemoresistance, and both serve as markers of CSCs $[35,36]$. LIN28A is a pluripotency factor expressed in embryonic stem cells (ESCs); its levels decrease during differentiation [37]. Carcinomas that highly express LIN28A are associated with poor survival, and LIN28A inhibition by let-7 results in reduced in vivo tumor progression [38,39]. HMGA2 is a chromatin-associated protein that facilitates gene transcription by binding $\mathrm{A} / \mathrm{T}$ rich sequences in proximity to the binding sites of specific transcription factors and modifying chromatin structure. HMGA2 facilitates embryonic stem cell exit from naïve to ground state, and is highly expressed during embryonic development, but is absent in differentiated cells [37,40]. HMGA2 is essential for ESC exit from pluripotency and for the onset of differentiation [40].

There are 13 let-7 family members encoding nine mature miRNAs. All have the same seed sequence and are thought to function in a similar manner. Evidence suggests that the slight differences in let-7 sequences change target preference, leading to slightly different functions [41]. While some let-7 family members act as tumor suppressors, others act as oncogenes [42-44]. Let-7 was also shown to be involved in double strand DNA break repair by directly or indirectly repressing several involved factors including BRCA1, RAD51, PARP, E2F1, and IGF1 [27,41,42,45-47]. Here, we focus on let-7i, one member of the let-7 family, due to its repression to a greater extent than other let-7 family members in our samples [34]. We demonstrate that let-7i up-regulation results in decreased stemness and self-renewal, reduced anchorage-independent growth, decreased functional phenotypes associated with cancer metastasis, increased apoptosis, and increased chemosensitivity to olaparib in BRCA wild-type (WT) samples.

\section{Results}

\subsection{Let-7 Over-Expression in PD HGSOC Samples}

Since both LIN28A and HGMA2 are established targets of let-7, a decrease in their levels provides confirmation of let-7i over-expression. Upon transient let-7i over-expression in PD samples and OVCAR8 cell line (Supplementary Figure S1), we observed repression of these targets on RNA (Figure 1A,B) and protein (Figure 1C-E) level. Full blot is shown in Supplementary Figure S2. Let-7i is lost to varying extents in ovarian cancer cells: levels are highest in OVCAR8, lower in PDX8, then PDX6, and lowest in PDX4 [34]. Because let-7 levels are comparatively higher, and pluripotency markers lower, in OVCAR8 [34], reductions in LIN28A and HMGA2 were modest on RNA level, and protein was not detected, in this cell line. Let-7 suppression of both LIN28A and HMGA2 in PD HGSOC samples is consistent with reduction of stemness.

\subsection{Let-7 Represses Self-Renewal}

While reduction of pluripotency factors suggests decreased stemness (Figure 1), the degree of reduction in functional terms is a more definitive measure. The self-renewal ability of cancer cells reflects their level of stemness and can be measured by the ability to form spheroids and colonies. A higher number of spheroids indicates a greater number of cancer stem cells present [48-50]. Let-7 up-regulation resulted in reduced number and size of spheroids (Figure 2A-C) and reduced number of colonies formed (Figure 2D,E). PDX8, OVCAR8, PDX4, and PDX6 are represented by i, ii, iii, and iv, respectively. Together 
with reduced LIN28A and HMGA2 expression, the reduced ability to form spheroids and colonies demonstrates the negative effect let-7 has on the number of cancer stem cells present within these populations.

A
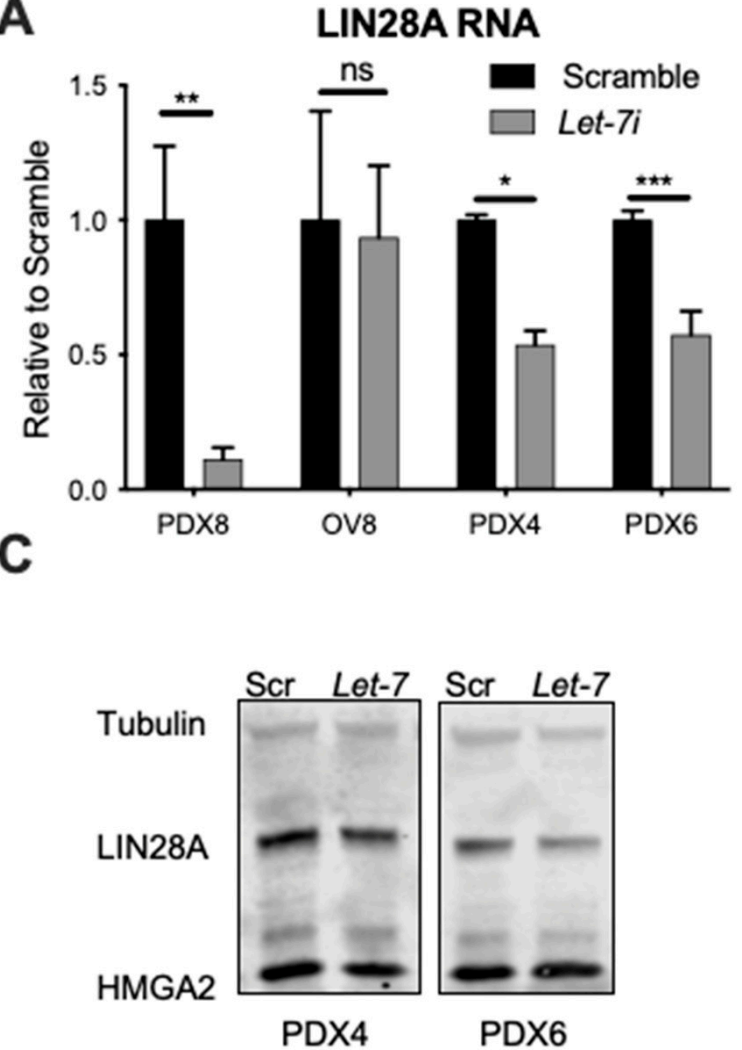

$\mathbf{E}$
B

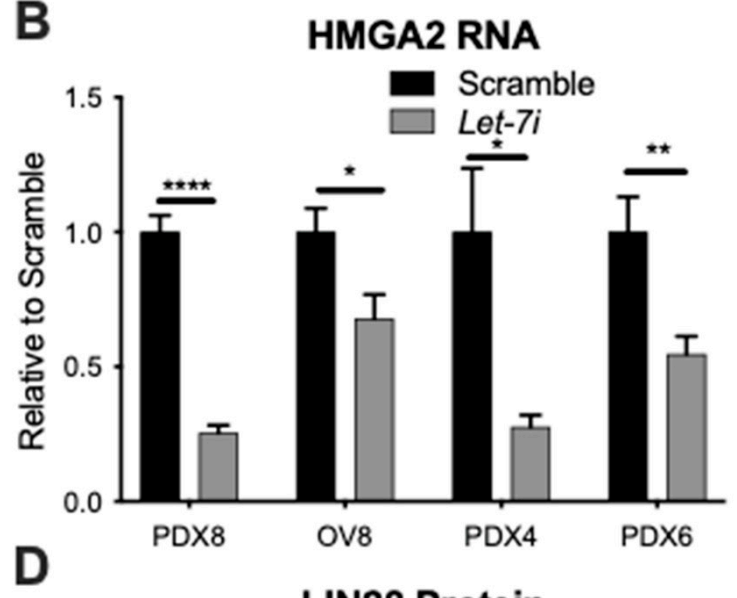

LIN28 Protein

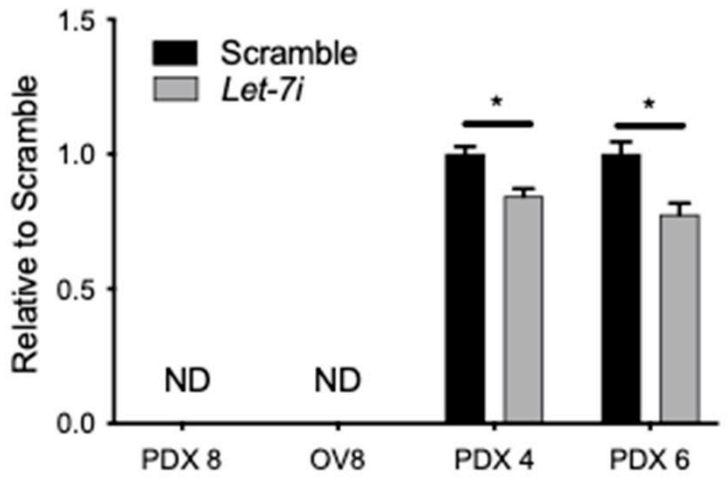

HMGA2 Protein

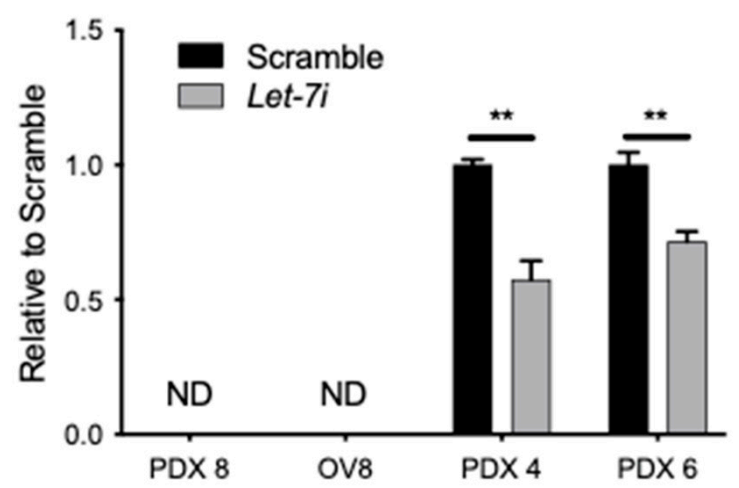

Figure 1. Let-7i up-regulation results in target repression. Let-7i mimic transfection resulted in repression of its targets LIN28A and/or HMGA2 on RNA (A,B) and protein (C) level, quantified in (D,E). LIN28A and HMGA2 protein levels were not detected (ND) in PDX8 and OVCAR8 samples due to very low expression. Student's $t$ test was used for statistical analysis. $\mathrm{N}=3+$ independent replicates. Error bars: standard error of the means (SEM). ${ }^{*} p \leq 0.05,{ }^{* *} p \leq 0.01,{ }^{* * *} p \leq 0.001$, ${ }^{* * * *} p \leq 0.0001 . p$ Value $\leq 0.05$ was considered significant. ns, not significant.

\subsection{Let-7 Represses Migration and Invasion of HGSOC}

To deduce the effect let-7 has on the functional phenotype of ovarian cancer cells, we utilized migration and invasion assays. Migration is an important factor in cancer metastasis. We analyzed the cell migration for $24 \mathrm{~h}$ upon let-7i over-expression and demonstrated 
a reduced kinetics of cell migration (Figure 3A and Supplementary Figure S3). While migratory abilities are important for cancer metastasis, invasion through the basement membrane is required for widespread dissemination [51]. Matrigel invasion assays were used to assess ability to invade. Significant reduction in invasion was seen in OVCAR8 with let-7 over-expression (Figure $3 \mathrm{C}$ and Supplementary Figure S4). Thus, let-7i overexpression led to reduced migratory and invasive abilities.

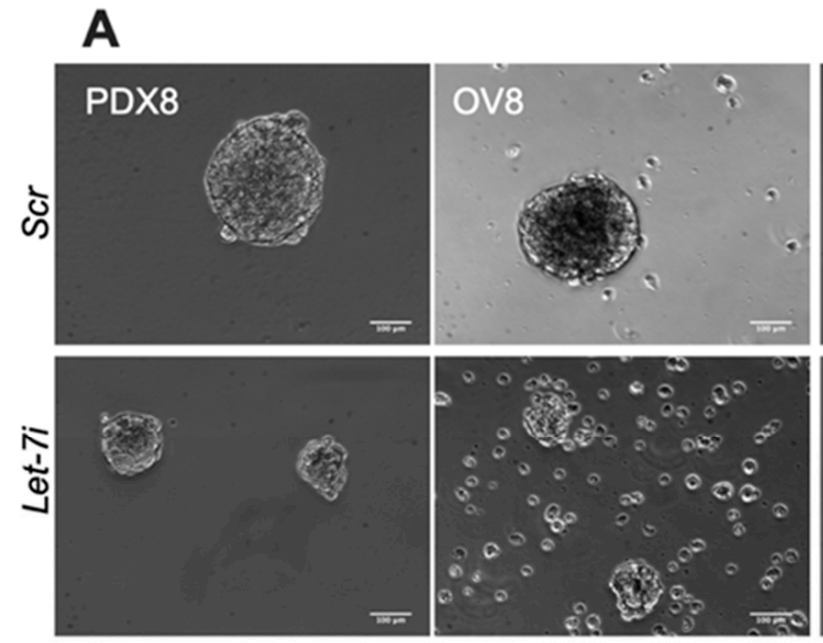

B
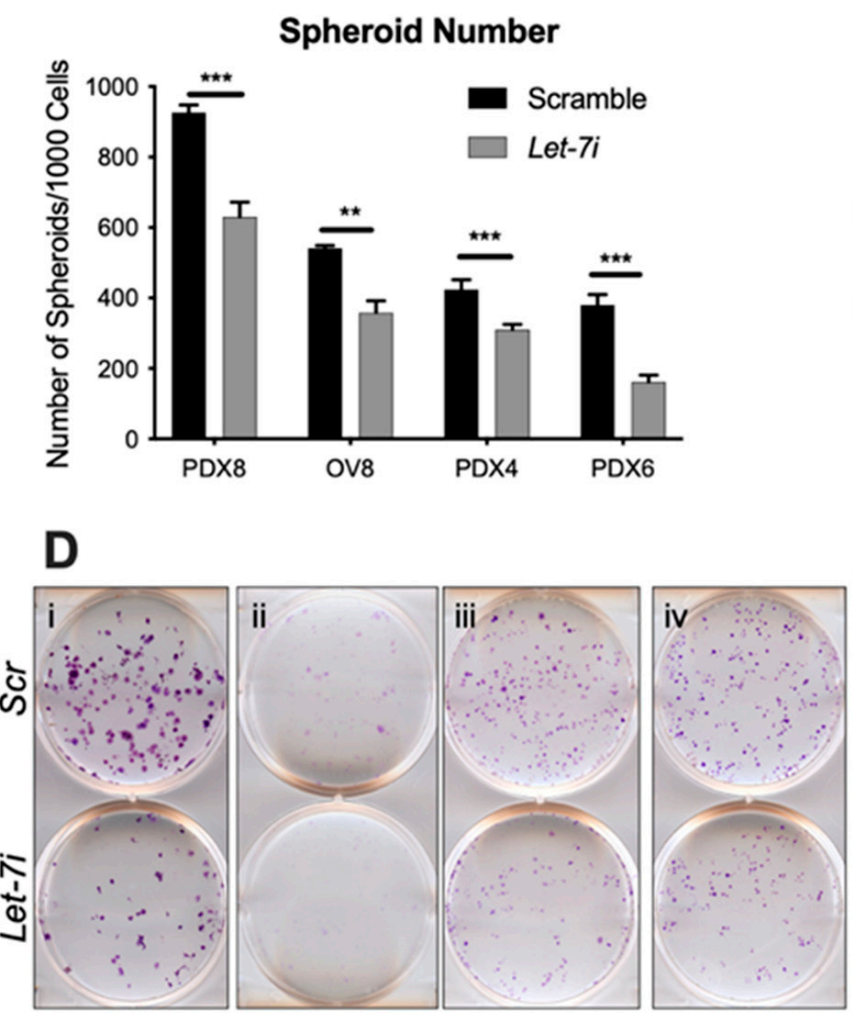

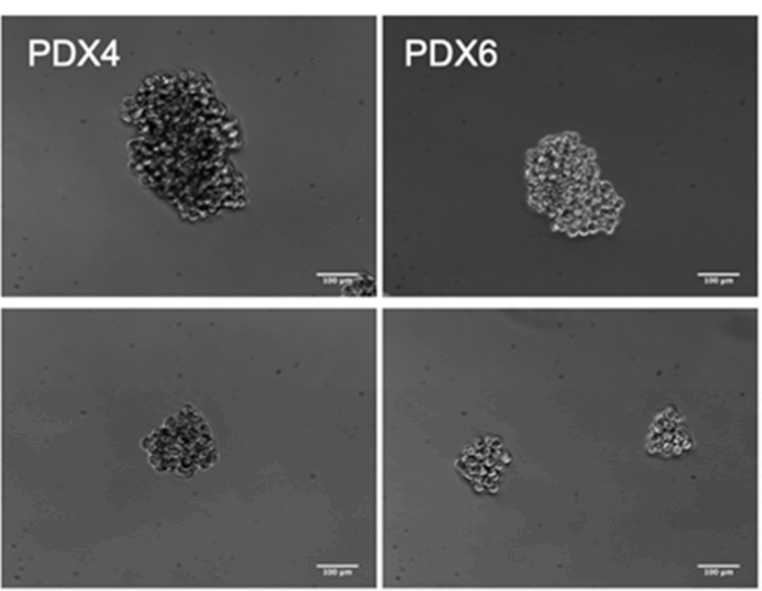

C

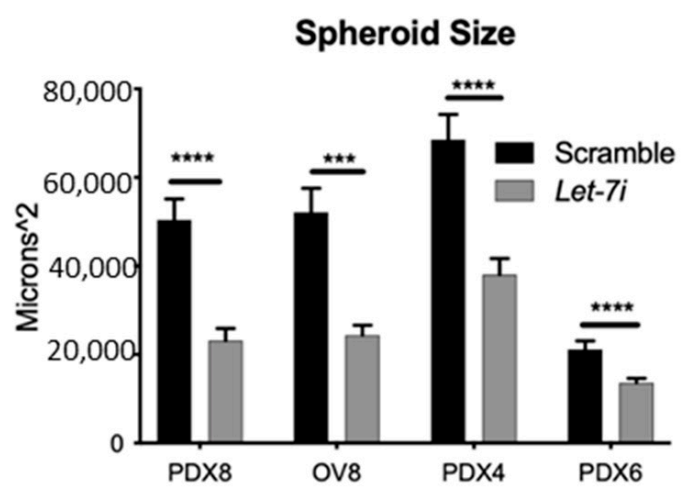

E

Colony Formation

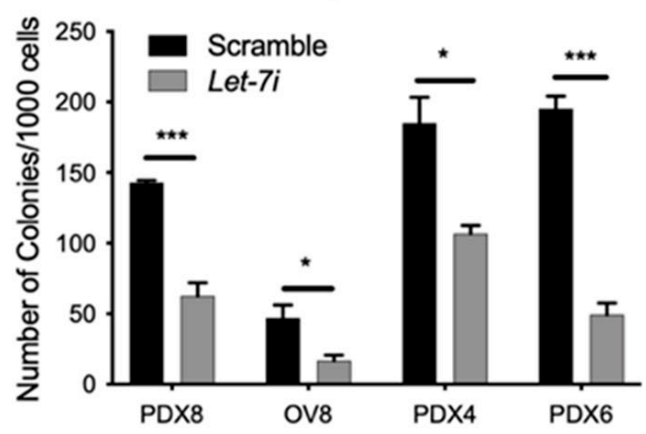

Figure 2. Let-7 represses self-renewal. Cells were grown in spheroid conditions. (A) Images of spheroids from cells as indicated with control (Scr, upper panel) or let-7i overexpression (lower panel). Scale bar: $100 \mu \mathrm{m}$. Let-7 transfection reduces number (B) and size (C) of spheroids. Let-7 over-expression results in reduced ability to form colonies (D). (E) i, ii, iii, and iv represent PDX8, OV8, PDX4, and PDX6, respectively. $\mathrm{N}=3+$ independent replicates. OV8, OVCAR8. Student's $t$ test was used for statistical analysis. Error bars: SEM. ${ }^{*} p \leq 0.05,{ }^{* *} p \leq 0.01,{ }^{* * *} p \leq 0.001,{ }^{* * * *} p \leq 0.0001 . p$ value $\leq 0.05$ was considered significant. 
A

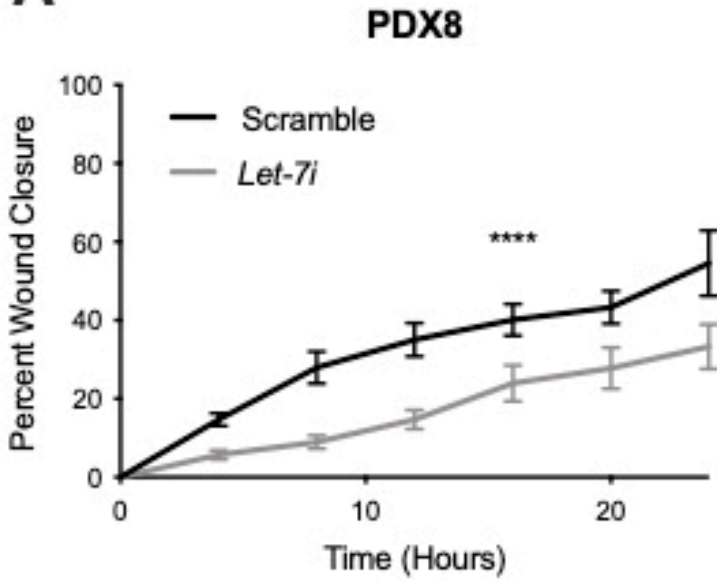

PDX4
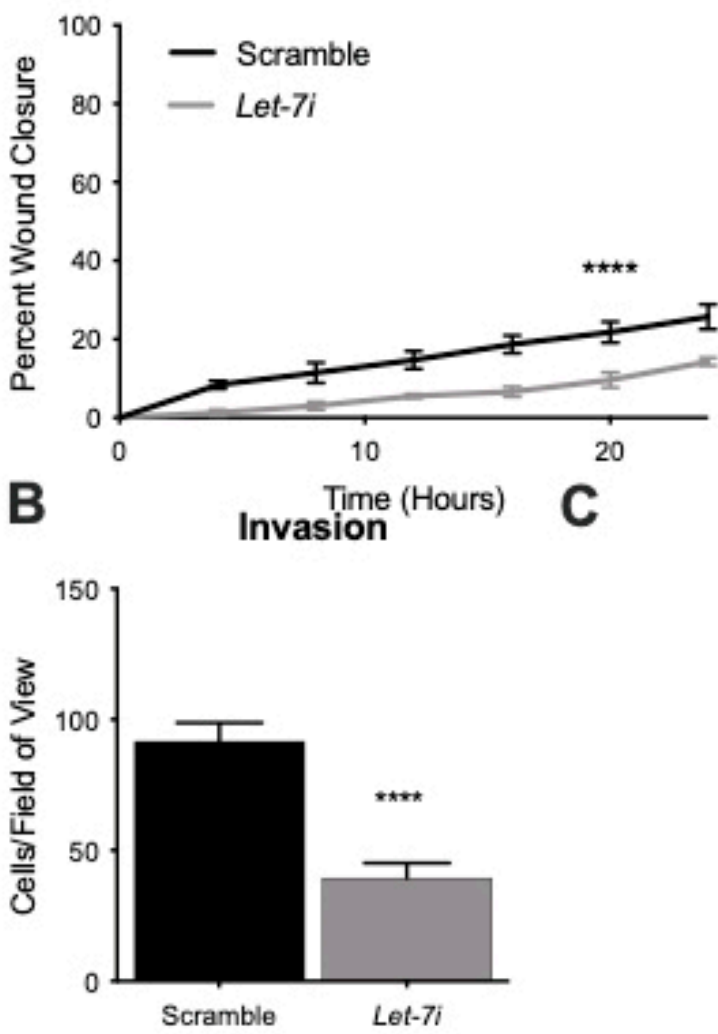

\section{OVCAR8}

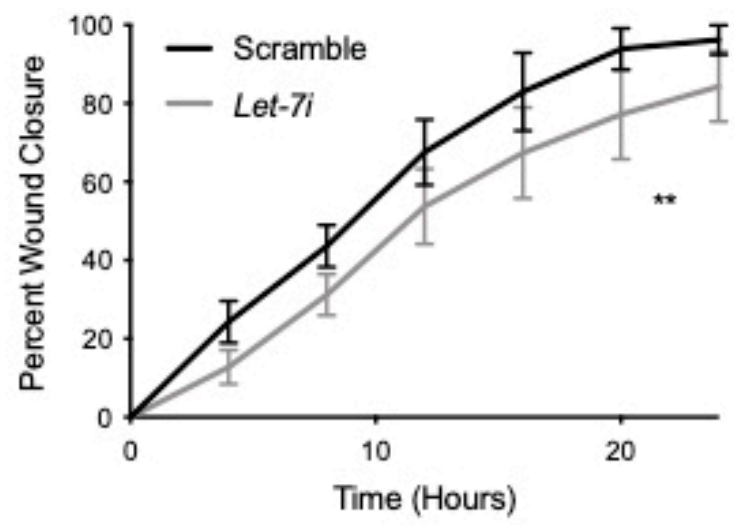

PDX6

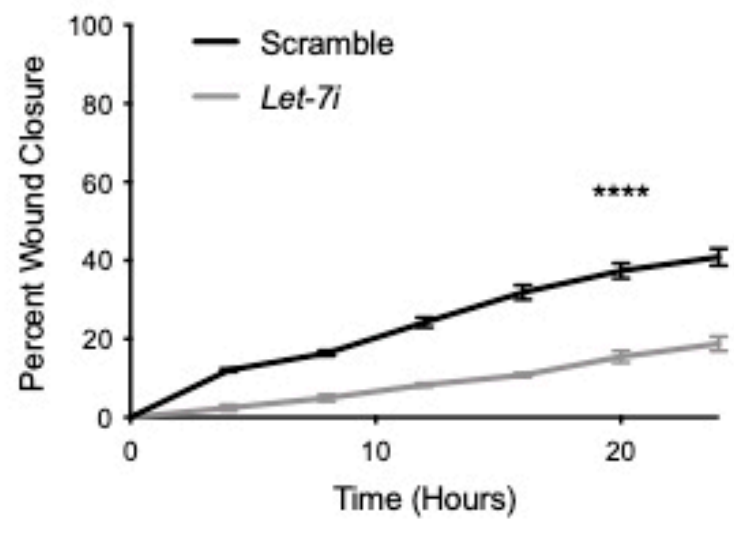

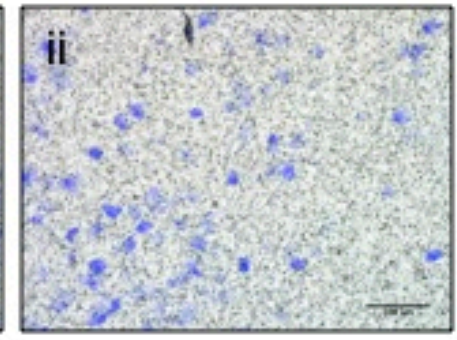

Figure 3. Let-7 reduces migration and invasion. Let-7 up-regulation demonstrates reduced ability to migrate (A) and invade $(\mathbf{B}, \mathbf{C}) . \mathrm{N}=3+$ independent replicates. $(\mathrm{C}) \mathrm{i}$ and ii represent Scramble and Let-7i, respectively. $\mathrm{N}=3$ independent replicates. Scale bar: $100 \mu \mathrm{m}$. Error bars: SEM. ${ }^{* *} p \leq 0.01,{ }^{* * *} p \leq 0.0001 . p$ value $\leq 0.05$ was considered significant.

\subsection{Let-7i Enhances HGSOC Sensitivity to PARP Inhibitors}

CSCs have been implicated in increased resistance to standard chemotherapies [52]. Because we observed that let-7i reduced pluripotency and self-renewal ability (Figures 1 and 2), we hypothesized that let-7i would also affect cell death, and found that increased let-7i expression alone was sufficient to significantly reduce cancer cell viability (Figure 4A). This effect was due to the induction of apoptosis (Supplementary Figure S5). Since PARP inhibitors are used as an adjuvant therapy to increase cancer cell death, we tested let-7i over-expression coupled with olaparib, an inhibitor of PARP. Two of our patient-derived 
samples, PDX4 and PDX6, possess mutations in the BRCA gene, which confers deficiency in homologous recombination repair (HRR). Two other samples, OVCAR8 and PDX8, demonstrated competent HRR [34]. Let-7i over-expression in PDX8 (Figure 4B) and OVCAR8 (Figure 4C) resulted in increased sensitivity to olaparib, while increased expression showed no effect in PDX4 (Figure 4D) and PDX6 (Figure 4E). Figure 4F represents reduction of chemoresistance represented by IC50, the drug concentration needed to decrease cell viability by fifty percent, by let-7i overexpression.

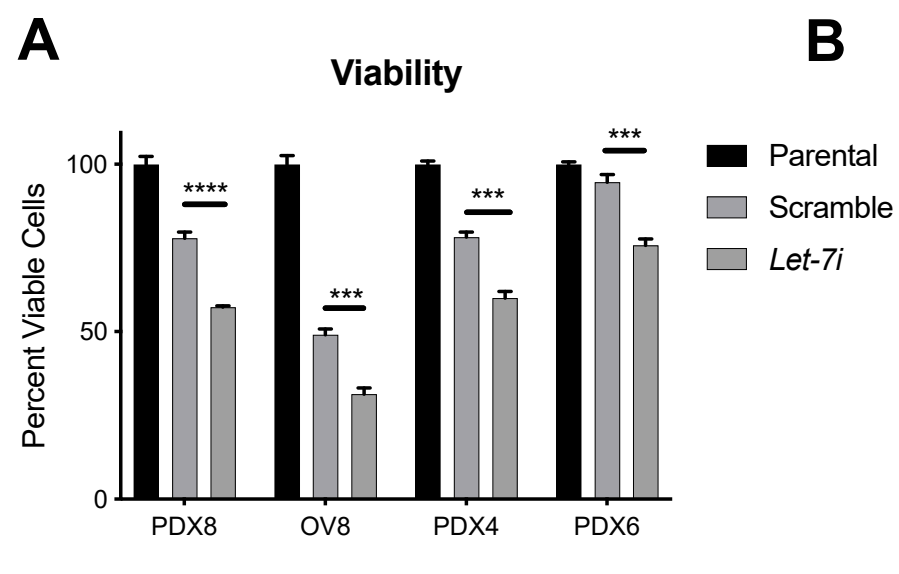

C

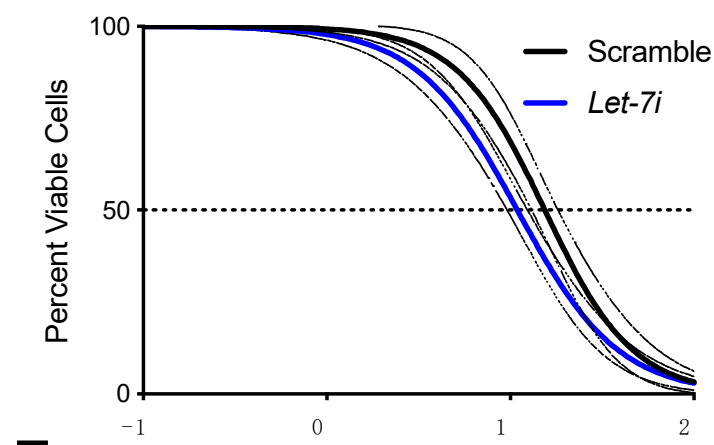

$\mathbf{E}$

Log Olaparib (UM)

PDX6

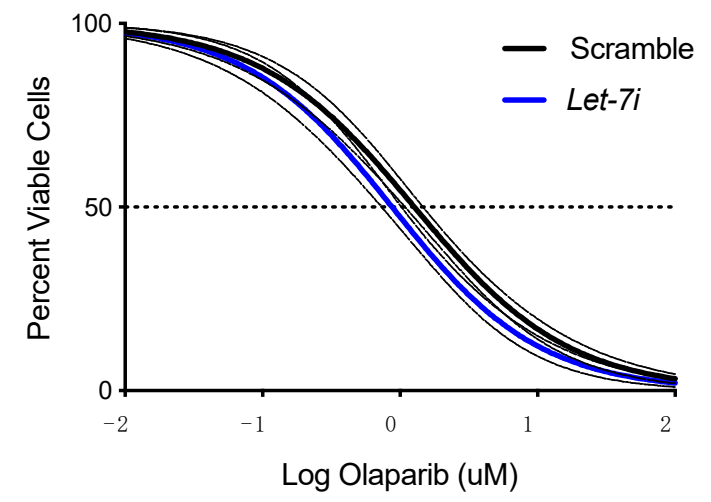

D
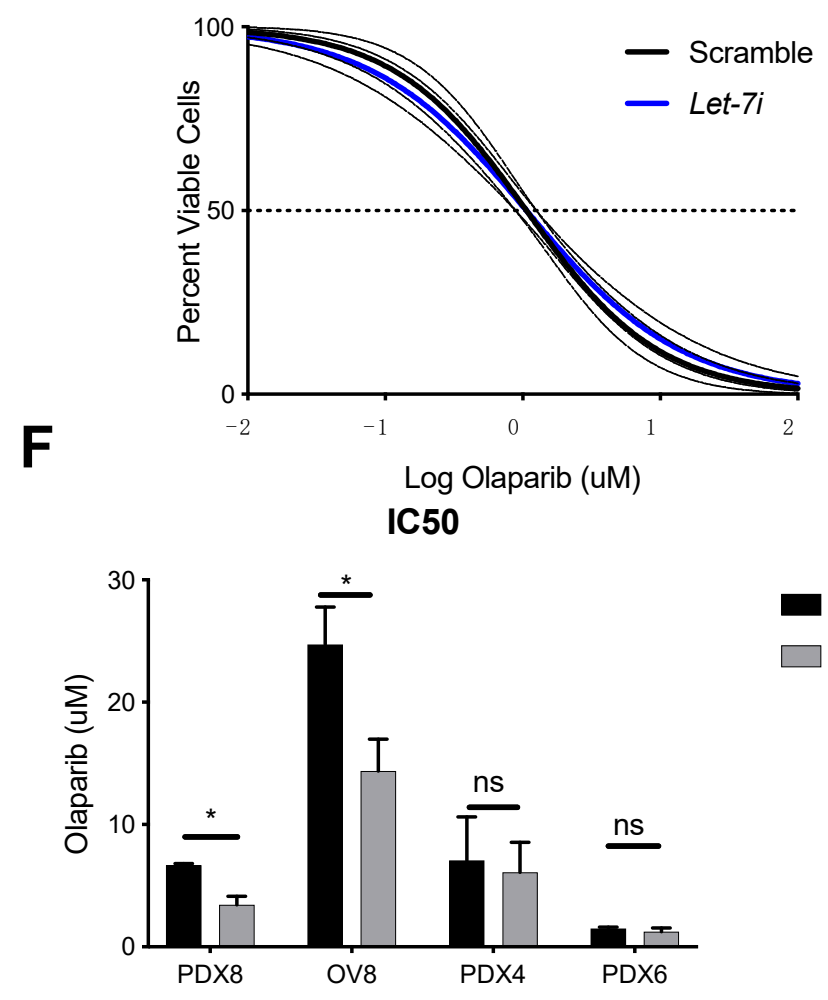

Figure 4. Let-7i effect on cancer cell viability and sensitivity to olaparib. Let-7i up-regulation resulted in reduced cell viability (A) and sensitivity to olaparib in HR competent samples (B,C). There was no effect on olaparib resistance in samples with BRCA1/2 mutation (D,E). (F) demonstrates IC50. N = 3+ independent replicates. Student's $t$ test was used for statistical analysis. Error bars: SEM. ${ }^{*} p \leq 0.05,{ }^{* * *} p \leq 0.001,{ }^{* * * *} p \leq 0.0001 . p$ value $\leq 0.05$ was considered significant. ns, not significant. 


\subsection{Let-7i Represses Factors Involved in HR Repair}

To determine the mechanism by which let-7i induces sensitivity to PARPi, we tested RNA levels of several known let-7 targets that play an important role in the HR repair pathway. Some of the targets include KRAS, MYC, IGF1, and E2F1 [53-56] As expected, let-7i over-expression resulted in repression of one or more of these targets on RNA level (Figure 5A-D), and protein level of cMYC (Supplementary Figure S6), demonstrating its effect via several different pathways.

A
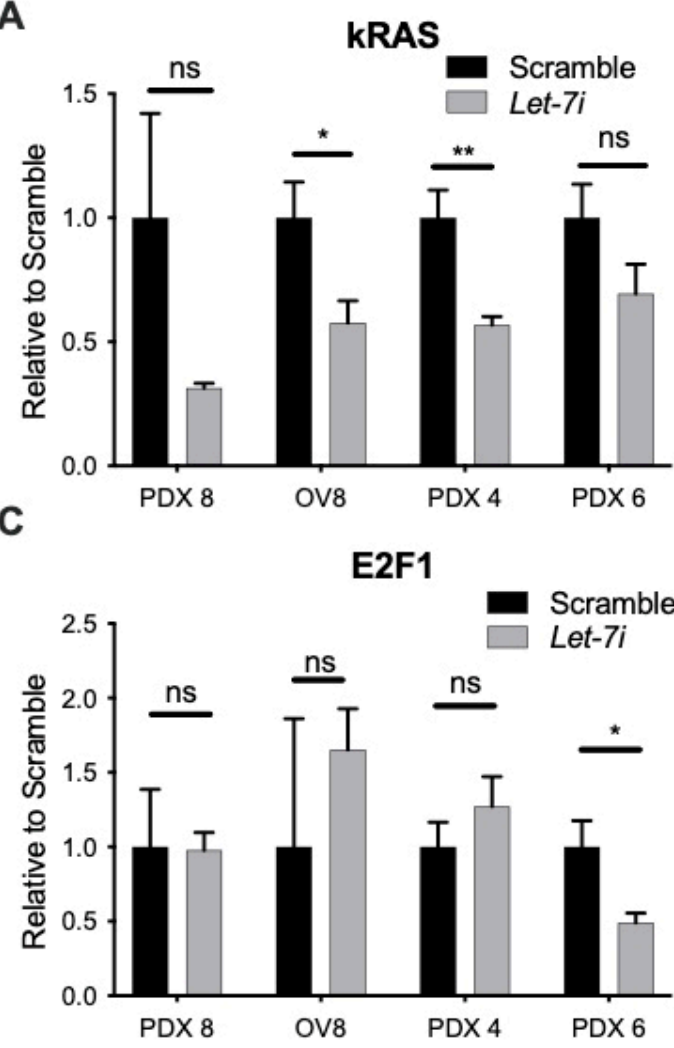

B

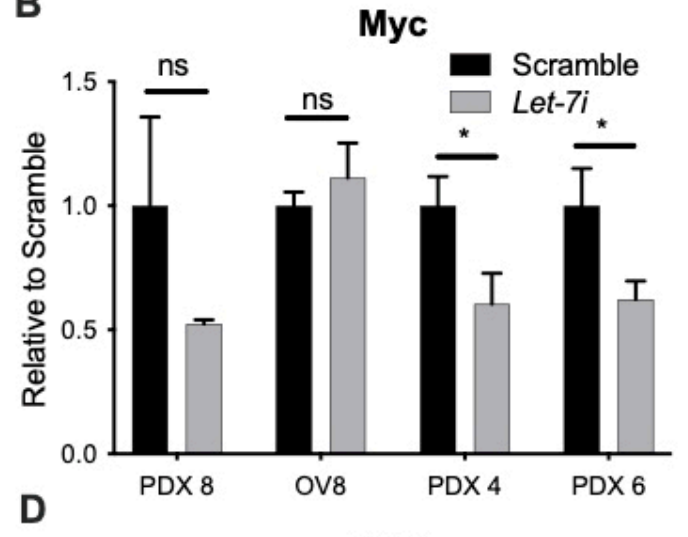

IGF1

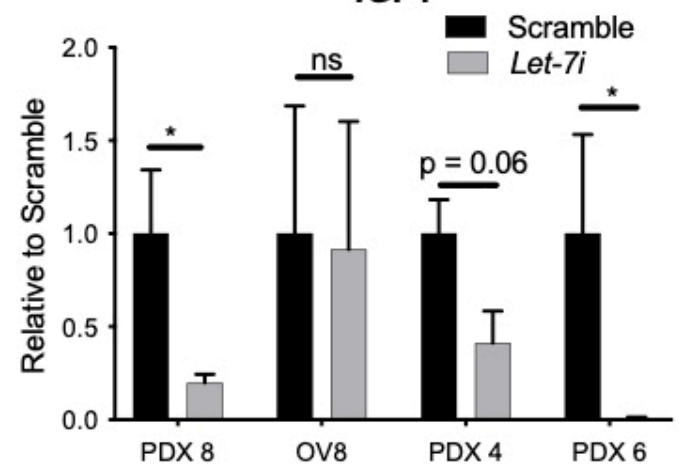

Figure 5. Let-7 represses targets involved in HR pathway. RT-qPCR demonstrates let-7i effect on KRAS (A), MYC (B), E2F1 (C), and IGF1 (D). Student's $t$ test used for statistical analysis. $\mathrm{N}=3+$ independent replicates. Error bars: SEM. ${ }^{*} p \leq 0.05$, ${ }^{* *} p \leq 0.01 . p$ value $\leq 0.05$ was considered significant. ns, not significant.

\section{Discussion}

In this study, we demonstrated let-7i's effect on pluripotency factor and CSC markers HGMA2 and LIN28A (Figure 1), revealing its action to reduce stemness of HGSOC. It has been shown that let-7 acts as a tumor suppressor by targeting pluripotency factors, including HMGA2 [57,58]. We utilized an experimental system that is more clinically relevant than cell lines: low passage patient-derived samples. By targeting proteins involved in pluripotency, let-7i effectively decreases the population of CSCs within the samples, demonstrated by the decreased ability to form colonies and spheroids (Figure 2). CSCs have been implicated in cancer progression, relapse, and chemoresistance [5,59].

Stemness in cancer cells is complex and multifactorial. Although some of the cells we described here (PDX8 and OVCAR8) form a high number of spheres, indicating their self-renewal ability, these same cells do not express high levels of stem cell markers LIN28A and HMGA2. Thus, other factors must explain the stemness attributes in these cells. Other candidates affecting self-renewal include MYC, EGFR, RAS, and EZH2 [60-63].

Distant metastasis remains the major cause for cancer-associated mortalities [64]. In order for this to occur, cancer cells must invade through the basement membrane and 
migrate through the tissues [65]. Here we show that let-7i represses the ability of ovarian cancer cells to migrate and invade (Figure 3). Let-7 targets (and downregulates) HMGA2, STAT3, PKM2, PBX3, KRAS, E2F1, ITGB3, and MAP4K3, which may explain its ability to decrease these properties $[41,46,66-71]$.

In recent years, PARPis have emerged as a class of potent treatment compounds most effective in tumor cells deficient in HR, one type of DNA damage repair. Let-7 targets several components of the HRR pathway, loss of which may therefore be an important factor in response to therapies targeting DNA damage repair, and let-7 levels may predict response to PARPi. PARP-1, the founding and most abundant member of a family of highly conserved enzymes, along with PARP-2, have an important role in signaling DNA single strand breaks (SSB). Inhibition of PARP activity thus leads to an accumulation of SSBs that convert to double strand breaks (DSB), leading to cell death unless repaired by HR. Let-7i overexpression results in increased sensitivity to olaparib in BRCA WT samples (Figure 4). This effect is possibly via repression of HR-associated components including KRAS, MYC, E2F1, and IGF, shown to be repressed with let-7 overexpression on the RNA level (Figure 5) and on the protein level in the case of c-MYC in two of four cell types (Supplementary Figure S6) [53-56]. Future studies will explore the mechanism of let-7 effect on BRCAness in more depth. PARPi therapy is most effective for patients with mutations in genes involved in HRR. By targeting and repressing several pathways involved in HRR, let-7 becomes a potential treatment that can be used to induce BRCAness phenotype in order to increase PARPi treatment efficacy in individuals without mutations in HRR genes.

Research on the molecular characterization of ovarian cancer on genomic, proteomic, and other levels has been ongoing for over a decade, launched by the flagship The Cancer Genome Atlas (TCGA) project [72]. Various scientific efforts have resulted in characterization of chromosomal aberrations, genomic rearrangements, and signaling pathway disruptions, as well as post-translational modifications [73,74]. Clinically, this has resulted in the development of tumor agnostic clinical trials, i.e., KEYNOTE trials [75,76]. Characterization of individual HGSOC tumors with these technologies allows for selection of individual therapy. In this investigation, we focused on the influence of miRNA let-7 $i$ on the HRR pathway and showed that let-7i overexpression contributes to the BRCAness phenotype, and ultimately targeted therapy sensitivity.

In this study, we have demonstrated the effect micro-RNA let-7i has on ovarian cancer phenotype and treatment. Ovarian cancer is a very complex disease that involves abnormalities in different aspects and levels of cellular functions. Because of this, a multidisciplinary approach must be utilized in order to diagnose and treat the disease more successfully. Combination of genomics, epigenomics, transcriptomics, and proteomics will provide us with a more complete picture of the disease progress and the treatment options most likely to succeed. Experts from multiple disciplines of medicine and research working together to treat patients will facilitate progress and enhance patient outcomes $[17,73,77,78]$.

\section{Materials and Methods}

\subsection{Cell Culture}

Tumor tissues were derived as described [34]; briefly, after informed consent, tumors were collected by Loma Linda University Cancer Center Biospecimen Laboratory. Of the set of eight patient-derived samples with in vitro growth characteristics that were conducive to these studies, the three with lowest let-7 levels were selected for these let-7i overexpression experiments. Cells from patient tumors were cultured in 75\% Ham's F12 (all media from Fisher Scientific, Waltham, MA, USA), 25\% DMEM with 5\% fetal bovine serum (FBS; Omega Scientific, Tarzana, CA, USA), $10 \mu \mathrm{M}$ insulin (chemicals are from Millipore/Sigma unless otherwise stated), $0.4 \mu \mathrm{M}$ hydrocortisone, $2 \mu \mathrm{g} / \mathrm{mL}$ isoprenaline, $24 \mu \mathrm{g} / \mathrm{mL}$ adenine, and $100 \mathrm{U} / \mathrm{mL}$ penicillin, $10 \mu \mathrm{g} / \mathrm{mL}$ streptomycin (pen/strep). Then, 5-10 $\mu \mathrm{M}$ Y27632 (Peprotech, East Windsor, NJ, USA) was added to initial cultures [79]. Patient-derived cells were used at passage 15 or less. 
Cell lines: OVCAR8 (human ovarian cancer; gift from Carlotta Glackin) were cultured in DMEM, 10\% FBS, $2 \mathrm{mM}$ L-glutamine, $0.1 \mathrm{mM} \mathrm{BME}$, and pen/strep; and NCCIT (embryonal carcinoma, from George Daley) in RPMI, 10\% FBS, 2 mM L-glutamine, 1\% non-essential amino acids, $1 \mathrm{mM}$ sodium pyruvate, and pen/strep.

\subsection{MicroRNA Let-7 Overexpression}

MiR-let-7i over-expression was achieved via lipofectamine (cat. 13778030, Life Technologies) transfection of mimics and scramble control purchased from IDTDNA. Upregulation was confirmed via RT-qPCR.

- Scramble S: 5'-mCmArUmArUmUrGmCrGmCrGmUrAmUrAmGrUmCrGC.

- Scramble AS: $5^{\prime}-/ 5$ Phos/rGrCrGrArCrUrArUrArCrGrCrGrCrArArUrArUmGmGrU-3'.

- Let-7i-5P S: 5'-mCmArGmCrAmCrAmArAmCrUmArCmUrAmCrCmUrCA-3'.

- Let-7i-5P AS: 5'-/5Phos/rUrGrArGrGrUrArGrUrArGrUrUrUrGrUrGrCrUmGmUrU-3'.

\subsection{Real-Time Quantitative Reverse-Transcription PCR (RT-qPCR)}

Total RNA from cell culture samples was isolated using TRIzol reagent (cat. 15596018, Life Technologies, Carlsbad, CA, USA) according to the manufacturer's instructions. For mRNA expression analysis, cDNA was synthesized with $1 \mu \mathrm{g}$ of total RNA using Thermo Scientific ${ }^{\mathrm{TM}}$ Maxima First Strand cDNA Synthesis Kit for RT-qPCR, with dsDNAse (K1672; ThermoFisher Scientific, Waltham, MA, USA). Real-time RTq-PCR for mRNA was performed using Applied Biosystems ${ }^{\mathrm{TM}}$ PowerUP ${ }^{\mathrm{TM}} \mathrm{SYBR}^{\mathrm{TM}}$ Green Master mix (A25778; Thermo Fisher Scientific, Waltham, MA, USA) and specific primers on a Stratagene Mx3005P qPCR System (Model: 401513; Agilent Technologies, Santa Clara, CA, USA). Primer sequences are shown in Supplementary Table S1. For analysis of miRNA expression, cDNA was synthesized using $100 \mathrm{ng}$ of total RNA with TaqMan primers (Life Technologies 4440887; let-7i assay 002221, U47 assay 001223) and Applied Biosystems ${ }^{\mathrm{TM}} \mathrm{TaqMan}^{\mathrm{TM}}$ mi- $^{\text {i }}$ croRNA Reverse Transcription Kit (4366596; Thermo Fisher Scientific, Waltham, MA, USA). For real-time RT-qPCR for miRNA, Applied Biosystems ${ }^{\mathrm{TM}}$ TaqMan $^{\mathrm{TM}}$ UniversalMaster Mix II (4440048; Thermo Fisher Scientific, Waltham, MA, USA) with TaqMan ${ }^{\mathrm{TM}}$ probes (Life Technologies) were used. Results were analyzed using the $\Delta \Delta$ cycles to threshold $(\Delta \Delta \mathrm{cT})$ method.

\subsection{Spheroid Formation Assay}

Spheroid formation assays were done as described [34]. Briefly, cells were plated at 1000 cells $/ \mathrm{mL}$ in non-tissue culture coated plates (Olympus) and maintained for seven days in spheroid media (DMEM/F12 50/50, 0.4\% bovine serum albumin, $10 \mathrm{ng} / \mathrm{mL}$ FGF, $20 \mathrm{ng} / \mathrm{mL}$ EGF, $6.7 \mathrm{ng} / \mathrm{mL}$ selenium, $5.5 \mu \mathrm{g} / \mathrm{mL}$ transferrin, $10 \mu \mathrm{g} / \mathrm{mL}$ insulin, and $1 \%$ knock out serum replacement (Gibco/ThermoFisher Scientific, Waltham, MA, USA)). Number and size of spheroids was then analyzed from phase contrast images using ImageJ software (National Institutes of Health, Bethesda, MD, USA).

\subsection{Scratch Assay (Wound Healing Cell Migration Assay)}

Wound healing assays were done as described [34]. Briefly, confluent cultures in 24-well cell culture plates were treated with mitomycin C (cat. S8146, Selleck Chemicals), scratchers were made with a $10 \mu \mathrm{L}$ pipet tip, and phase contrast images of several positions along the length of the scratch were taken every four hours for $24 \mathrm{~h}$ with a Nikon Eclipse Ti microscope using MicroManager [80], analyzed with ImageJ (National Institutes of Health, Bethesda, MD, USA).

\subsection{Western Blot}

Lysates of cells in Laemmli buffer were sonicated, proteins were separated by SDSPAGE and transferred to a $0.45 \mu \mathrm{M}$ PVDF membrane (Fisher Scientific, Waltham, MA, USA). Membrane was blocked with $0.1-5 \%$ milk in TBST for $1 \mathrm{~h}$. Primary antibodies were applied at 1:1000 dilution overnight, followed by immunoblotting. The membrane was stained with 
the antibodies at the same time given that the diluents were compatible and the location of the bands was detected individually in a prior experiment. Secondary antibodies (antirabbit IgG conjugated to Dylight 680, Fisher Scientific, Waltham, MA, USA) were applied for an hour at 1:30,000 dilution. Primary antibodies (Cell Signaling Technology, Danvers, MA, USA) included $\alpha / \beta$-tubulin (21485), LIN28A (39785), and HMGA2 (81795). Secondary antibody immunoblotting was done with anti-rabbit IgG conjugated with Dylight 680 or 800 (Invitrogen, Carlsbad, CA, USA). Membranes were imaged with LI-COR Odyssey CLx Infrared Imaging System (LI-COR Biosciences, Lincoln, NE, USA) and analyzed with ImageJ software (National Institutes of Health, Bethesda, MD, USA). Full Western blots are shown in Supplementary Figure S2.

\subsection{Invasion Assay}

Invasion assay was derived based on a previously published protocol [81], as described [34]. Briefly, cells were cultured for $24 \mathrm{~h}$ in their respective media without FBS, then dissociated as usual with $0.05 \%$ trypsin/EDTA, resuspended in serum-free media, and 20,000 cells (PDX4 and PDX6) or 50,000 cells (PDX8 and OVCAR8) were plated on inserts. Cell number was optimized for proliferation rate; for quantification, samples with 50,000 cells were normalized to 20,000. Transwell inserts (Genesee Scientific, San Diego, CA, USA) were coated with $0.1 \mu \mathrm{g}$ Basement Membrane Extract (BME) (3433-010-01) in 1X Cultrex coating buffer (3455-096-03) (Trevigen, Gaithersburg, MD, USA). Complete media (containing FBS) was placed in a lower chamber. After $24 \mathrm{~h}$, the tops of inserts were wiped clean with a cotton tipped applicator, inserts were fixed in $70 \%$ ethanol for $15 \mathrm{~min}$, stained in $0.2 \%$ crystal violet for $10-15 \mathrm{~min}$, rinsed with distilled $\mathrm{H}_{2} \mathrm{O}$, and allowed to dry. Cells were imaged $(100 \times)$ using Leica DMi1 inverted microscope and counted using ImageJ.

\subsection{Statistical Analysis}

GraphPadPrism version 7.0 (GraphPad Software, La Jolla, CA, USA) was used to prepare figures and for statistical analysis. Statistical analysis methods are described in figure legends.

\section{Conclusions}

We have demonstrated repressive actions of let-7i on HGSOC cell stemness, resulting in reduced ability to self-renew, a feature necessary for cancer recurrence. We have also demonstrated let-7i actions on cancer metastasis by repressing the ability to migrate and invade. Let-7i actions on chemoresistance to PARPi olaparib is more complex. While let-7i has no effect on chemoresistance to olaparib in samples with BRCA1/2 mutation, its upregulation in wild type samples resulted in increased sensitivity. The induction of sensitivity is presumed to be due to the repression of one or more of the factors involved in the HRR pathway including KRAS, MYC, E2F1, and IGF1. Taken together, these data suggest the possibility of using let-7i as an adjunct to standard therapy as well as an addition to PARPi for patients that do not have BRCA1/2 mutations.

Supplementary Materials: The following are available online at https:/ / www.mdpi.com/article/ 10.3390/cancers13184617/s1, Figure S1: Let-7 transfection, Figure S2: Full images of Western blots, Figure S3: Images from wound healing assays, Figure S4: Let-7 reduces invasion, Figure S5: Let-7 increases apoptosis, Figure S6: Let-7 effect on cMYC protein level, Table S1, RT-qPCR Primers.

Author Contributions: Conceptualization, E.C. and J.J.U.; methodology, E.C., T.S., A.N., N.H., L.S. and J.J.U.; validation, E.C. and T.S.; formal analysis, E.C., T.S., H.W. and J.J.U.; investigation, E.C., T.S. and H.W.; resources, S.M. and Y.J.I.; data curation, E.C., T.S., H.W. and J.J.U.; writing-original draft preparation, E.C. and J.J.U.; writing—review and editing, E.C., T.S., H.W., L.S., Y.J.I. and J.J.U.; visualization, E.C. and H.W.; supervision, J.J.U.; project administration, E.C. and J.J.U.; funding acquisition, J.J.U. All authors have read and agreed to the published version of the manuscript. 
Funding: This research was funded by an Inception grant from California Institute for Regenerative Medicine, grant number DISC1-10588 to J.J.U., Grant to Promote Collaboration and Translation from Loma Linda University, grant number 2170240 to J.J.U. and Y.J.I.

Institutional Review Board Statement: All studies were approved by the Loma Linda University (LLU) IRB (\#58238, approved 24 January 2018). Investigations were carried out following the rules of the Declaration of Helsinki of 1975.

Informed Consent Statement: All subjects gave their informed consent before participation in the study.

Data Availability Statement: Data will be made available from the corresponding author upon reasonable request.

Acknowledgments: We thank Carlotta Glackin for cells, Shannalee Martinez for assistance with assay development, Kerby Oberg for insightful comments on the manuscript, and members of the Unternaehrer laboratory for helpful discussions.

Conflicts of Interest: The authors declare no conflict of interest.

\section{References}

1. SEER Cancer Stat Facts: Ovarian Cancer; National Cancer Institute: Bethesda, MD, USA. Available online: https://seer.cancer.gov / statfacts / html/ovary.html (accessed on 27 June 2021).

2. Siegel, R.L.; Miller, K.D.; Jemal, A. Cancer statistics, 2020. CA Cancer J. Clin. 2020, 70, 7-30. [CrossRef] [PubMed]

3. Horowitz, N.S.; Miller, A.; Rungruang, B.; Richard, S.D.; Rodriguez, N.; Bookman, M.A.; Hamilton, C.A.; Krivak, T.C.; Maxwell, G.L. Does Aggressive Surgery Improve Outcomes? Interaction Between Preoperative Disease Burden and Complex Surgery in Patients with Advanced-Stage Ovarian Cancer: An Analysis of GOG 182. J. Clin. Oncol. 2015, 33, 937-943. [CrossRef] [PubMed]

4. Hoppenot, C.; Eckert, M.; Tienda, S.M.; Lengyel, E. Who are the long-term survivors of high grade serous ovarian cancer? Gynecol. Oncol. 2018, 148, 204-212. [CrossRef] [PubMed]

5. Beck, B.; Blanpain, C. Unravelling cancer stem cell potential. Nat. Rev. Cancer 2013, 13, 727-738. [CrossRef] [PubMed]

6. Friedrich, M.; Friedrich, D.; Kraft, C.; Rogmans, C. Multimodal Treatment of Primary Advanced Ovarian Cancer. Anticancer. Res. 2021, 41, 3253-3260. [CrossRef]

7. Cortez, A.J.; Tudrej, P.; Kujawa, K.; Lisowska, K.M. Advances in ovarian cancer therapy. Cancer Chemother. Pharmacol. 2017, 81, 17-38. [CrossRef]

8. Vergote, I.; Coens, C.; Nankivell, M.; Kristensen, G.B.; Parmar, M.K.B.; Ehlen, T.; Jayson, G.; Johnson, N.; Swart, A.M.; Verheijen, R.; et al. Neoadjuvant chemotherapy versus debulking surgery in advanced tubo-ovarian cancers: Pooled analysis of individual patient data from the EORTC 55971 and CHORUS trials. Lancet Oncol. 2018, 19, 1680-1687. [CrossRef]

9. Kuroki, L.; Guntupalli, S.R. Treatment of epithelial ovarian cancer. BMJ 2020, 371, m3773. [CrossRef]

10. Byrum, A.; Vindigni, A.; Mosammaparast, N. Defining and Modulating 'BRCAness'. Trends Cell Biol. 2019, 29, 740-751. [CrossRef]

11. Gupta, S.; Nag, S.; Aggarwal, S.; Rauthan, A.; Warrier, N. Maintenance therapy for recurrent epithelial ovarian cancer: Current therapies and future perspectives-A review. J. Ovarian Res. 2019, 12, 1-15. [CrossRef]

12. Coleman, R.L.; Oza, A.; Lorusso, D.; Aghajanian, C.; Oaknin, A.; Dean, A.; Colombo, N.; Weberpals, J.I.; Clamp, A.; Scambia, G.; et al. Rucaparib maintenance treatment for recurrent ovarian carcinoma after response to platinum therapy (ARIEL3): A randomised, double-blind, placebo-controlled, phase 3 trial. Lancet 2017, 390, 1949-1961. [CrossRef]

13. Moore, K.N.; Secord, A.A.; Geller, M.A.; Miller, D.; Cloven, N.; Fleming, G.F.; Hendrickson, A.E.W.; Azodi, M.; DiSilvestro, P.; Oza, A.; et al. Niraparib monotherapy for late-line treatment of ovarian cancer (QUADRA): A multicentre, open-label, single-arm, phase 2 trial. Lancet Oncol. 2019, 20, 636-648. [CrossRef]

14. Martín, A.G.; Pothuri, B.; Vergote, I.; Christensen, R.D.; Graybill, W.; Mirza, M.R.; McCormick, C.; Lorusso, D.; Hoskins, P.; Freyer, G.; et al. Niraparib in Patients with Newly Diagnosed Advanced Ovarian Cancer. N. Engl. J. Med. 2019, 381, $2391-2402$. [CrossRef] [PubMed]

15. Mirza, M.R.; Monk, B.J.; Herrstedt, J.; Oza, A.; Mahner, S.; Redondo, A.; Fabbro, M.; Ledermann, J.A.; Lorusso, D.; Vergote, I.; et al. Niraparib Maintenance Therapy in Platinum-Sensitive, Recurrent Ovarian Cancer. N. Engl. J. Med. 2016, 375, $2154-2164$. [CrossRef]

16. Poveda, A.; Floquet, A.; Ledermann, J.A.; Asher, R.; Penson, R.T.; Oza, A.M.; Korach, J.; Huzarski, T.; Pignata, S.; Friedlander, M.; et al. Olaparib tablets as maintenance therapy in patients with platinum-sensitive relapsed ovarian cancer and a BRCA1/2 mutation (SOLO2/ENGOT-Ov21): A final analysis of a double-blind, randomised, placebo-controlled, phase 3 trial. Lancet Oncol. 2021, 22, 620-631. [CrossRef]

17. Falzone, L.; Scandurra, G.; Lombardo, V.; Gattuso, G.; Lavoro, A.; Distefano, A.B.; Scibilia, G.; Scollo, P. A multidisciplinary approach remains the best strategy to improve and strengthen the management of ovarian cancer (Review). Int. J. Oncol. 2021, 59, 1-14. [CrossRef] 
18. Jiang, X.; Li, W.; Li, X.; Bai, H.; Zhang, Z. Current status and future prospects of PARP inhibitor clinical trials in ovarian cancer. Cancer Manag. Res. 2019, ume 11, 4371-4390. [CrossRef]

19. An, D.; Banerjee, S.; Lee, J.-M. Recent advancements of antiangiogenic combination therapies in ovarian cancer. Cancer Treat. Rev. 2021, 98, 102224. [CrossRef] [PubMed]

20. Siomi, H.; Siomi, M.C. Posttranscriptional Regulation of MicroRNA Biogenesis in Animals. Mol. Cell 2010, 38, 323-332. [CrossRef] [PubMed]

21. Yang, H.; Kong, W.; He, L.; Zhao, J.-J.; O’Donnell, J.D.; Wang, J.; Wenham, R.M.; Coppola, D.; Kruk, P.A.; Nicosia, S.V.; et al MicroRNA Expression Profiling in Human Ovarian Cancer: miR-214 Induces Cell Survival and Cisplatin Resistance by Targeting PTEN. Cancer Res. 2008, 68, 425-433. [CrossRef] [PubMed]

22. Reinhart, B.J.; Slack, F.; Basson, M.; Pasquinelli, A.E.; Bettinger, J.C.; Rougvie, A.E.; Horvitz, H.R.; Ruvkun, G. The 21-nucleotide let-7 RNA regulates developmental timing in Caenorhabditis elegans. Nature 2000, 403, 901-906. [CrossRef]

23. Hayes, G.D.; Ruvkun, G. Misexpression of the Caenorhabditis elegans miRNA let-7 Is Sufficient to Drive Developmental Programs. Cold Spring Harb. Symp. Quant. Biol. 2006, 71, 21-27. [CrossRef]

24. Unternaehrer, J.J.; Zhao, R.; Kim, K.; Cesana, M.; Powers, J.T.; Ratanasirintrawoot, S.; Onder, T.; Shibue, T.; Weinberg, R.A.; Daley, G.Q. The Epithelial-Mesenchymal Transition Factor SNAIL Paradoxically Enhances Reprogramming. Stem Cell Rep. 2014, 3 , 691-698. [CrossRef] [PubMed]

25. Worringer, K.; Rand, T.A.; Hayashi, Y.; Sami, S.; Takahashi, K.; Tanabe, K.; Narita, M.; Srivastava, D.; Yamanaka, S. The let-7/LIN41 Pathway Regulates Reprogramming to Human Induced Pluripotent Stem Cells by Controlling Expression of Prodifferentiation Genes. Cell Stem Cell 2013, 14, 40-52. [CrossRef] [PubMed]

26. Melton, C.; Judson, R.L.; Blelloch, R. Opposing microRNA families regulate self-renewal in mouse embryonic stem cells. Nature 2010, 463, 621-626. [CrossRef]

27. Xiao, M.; Cai, J.; Cai, L.; Jia, J.; Xie, L.; Zhu, Y.; Huang, B.; Jin, D.; Wang, Z. Let-7e sensitizes epithelial ovarian cancer to cisplatin through repressing DNA double strand break repair. J. Ovarian Res. 2017, 10, 1-13. [CrossRef]

28. Song, H.; Zhang, Y.; Liu, N.; Zhang, D.; Wan, C.; Zhao, S.; Kong, Y.; Yuan, L. Let-7b inhibits the malignant behavior of glioma cells and glioma stem-like cells via downregulation of E2F2. J. Physiol. Biochem. 2016, 72, 733-744. [CrossRef]

29. Sun, X.; Xu, C.; Tang, S.-C.; Wang, J.; Wang, H.; Wang, P.; Du, N.; Qin, S.; Li, G.; Xu, S.; et al. Let-7c blocks estrogen-activated Wnt signaling in induction of self-renewal of breast cancer stem cells. Cancer Gene Ther. 2016, 23, 83-89. [CrossRef]

30. Lee, H.; Han, S.; Kwon, C.S.; Lee, D. Biogenesis and regulation of the let-7 miRNAs and their functional implications. Protein Cell 2015, 7, 100-113. [CrossRef] [PubMed]

31. Yang, W.-H.; Lan, H.-Y.; Huang, C.-H.; Tai, S.-K.; Tzeng, C.-H.; Kao, S.-Y.; Wu, K.-J.; Hung, M.-C.; Yang, M.-H. RAC1 activation mediates Twist1-induced cancer cell migration. Nature 2012, 14, 366-374. [CrossRef] [PubMed]

32. Shyh-Chang, N.; Daley, G.Q. Lin28: Primal Regulator of Growth and Metabolism in Stem Cells. Cell Stem Cell 2013, 12, 395-406. [CrossRef] [PubMed]

33. Wang, H.; Chirshev, E.; Hojo, N.; Suzuki, T.; Bertucci, A.; Pierce, M.; Perry, C.; Wang, R.; Zink, J.; Glackin, C.; et al. The Epithelial-Mesenchymal Transcription Factor SNAI1 Represses Transcription of the Tumor Suppressor miRNA let-7 in Cancer. Cancers 2021, 13, 1469. [CrossRef] [PubMed]

34. Chirshev, E.; Hojo, N.; Bertucci, A.; Sanderman, L.; Nguyen, A.; Wang, H.; Suzuki, T.; Brito, E.; Martinez, S.; Castañón, C.; et al. Epithelial/mesenchymal heterogeneity of high-grade serous ovarian carcinoma samples correlates with miRNA let-7 levels and predicts tumor growth and metastasis. Mol. Oncol. 2020, 14, 2796-2813. [CrossRef]

35. Zhou, J.; Ng, S.-B.; Chng, W.-J. LIN28/LIN28B: An emerging oncogenic driver in cancer stem cells. Int. J. Biochem. Cell Biol. 2013, 45, 973-978. [CrossRef]

36. Büssing, I.; Slack, F.; Grosshans, H. let-7 microRNAs in development, stem cells and cancer. Trends Mol. Med. 2008, 14, 400-409. [CrossRef] [PubMed]

37. Parisi, S.; Passaro, F.; Russo, L.; Musto, A.; Navarra, A.; Romano, S.; Petrosino, G.; Russo, T. Lin28 is induced in primed embryonic stem cells and regulates let-7-independent events. FASEB J. 2016, 31, 1046-1058. [CrossRef] [PubMed]

38. He, Y.; Wang, H.; Yan, M.; Yang, X.; Shen, R.; Ni, X.; Chen, X.; Yang, P.; Chen, M.; Lu, X.; et al. High LIN28A and PLK4 co-expression is associated with poor prognosis in epithelial ovarian cancer. Mol. Med. Rep. 2018, 18, 5327-5336. [CrossRef] [PubMed]

39. Albino, D.; Civenni, G.; Dallavalle, C.; Roos, M.; Jahns, H.; Curti, L.; Rossi, S.; Pinton, S.; D'Ambrosio, G.; Sessa, F.; et al. Activation of the Lin28/let-7 Axis by Loss of ESE3/EHF Promotes a Tumorigenic and Stem-like Phenotype in Prostate Cancer. Cancer Res. 2016, 76, 3629-3643. [CrossRef]

40. Navarra, A.; Musto, A.; Gargiulo, A.; Petrosino, G.; Pierantoni, G.M.; Fusco, A.; Russo, T.; Parisi, S. Hmga2 is necessary for Otx2-dependent exit of embryonic stem cells from the pluripotent ground state. BMC Biol. 2016, 14, 1-17. [CrossRef] [PubMed]

41. Chirshev, E.; Oberg, K.; Ioffe, Y.J.; Unternaehrer, J.J. Let-7as biomarker, prognostic indicator, and therapy for precision medicine in cancer. Clin. Transl. Med. 2019, 8, 24. [CrossRef] [PubMed]

42. Wang, Y.; Bao, W.; Liu, Y.; Wang, S.; Xu, S.; Li, X.; Li, Y.; Wu, S. miR-98-5p contributes to cisplatin resistance in epithelial ovarian cancer by suppressing miR-152 biogenesis via targeting Dicer1. Cell Death Dis. 2018, 9, 1-17. [CrossRef]

43. Brueckner, B.; Stresemann, C.; Kuner, R.; Mund, C.; Musch, T.; Meister, M.; Sültmann, H.; Lyko, F. The Human let-7a-3 Locus Contains an Epigenetically Regulated MicroRNA Gene with Oncogenic Function. Cancer Res. 2007, 67, 1419-1423. [CrossRef] 
44. Shi, W.; Zhang, Z.; Yang, B.; Guo, H.; Jing, L.; Liu, T.; Luo, Y.; Liu, H.; Li, Y.; Gao, Y. Overexpression of microRNA let-7 correlates with disease progression and poor prognosis in hepatocellular carcinoma. Medicine 2017, 96, e7764. [CrossRef] [PubMed]

45. Wielgos, M.E.; Rajbhandari, R.; Cooper, T.S.; Wei, S.; Nozell, S.; Yang, E.S. Let-7 Status Is Crucial for PARP1 Expression in HER2-Overexpressing Breast Tumors. Mol. Cancer Res. 2016, 15, 340-347. [CrossRef] [PubMed]

46. Huang, Y.; Hong, X.; Hu, J.; Lu, Q. Targeted regulation of MiR-98 on E2F1 increases chemosensitivity of leukemia cells K562/A02. OncoTargets Ther. 2017, ume 10, 3233-3239. [CrossRef]

47. Shen, G.; Wu, R.; Liu, B.; Dong, W.; Tu, Z.; Yang, J.; Xu, Z.; Pan, T. Upstream and downstream mechanisms for the promoting effects of IGF-1 on differentiation of spermatogonia to primary spermatocytes. Life Sci. 2014, 101, 49-55. [CrossRef]

48. Yu, F.; Yao, H.; Zhu, P.; Zhang, X.; Pan, Q.; Gong, C.; Huang, Y.; Hu, X.; Su, F.; Lieberman, J.; et al. let-7 Regulates Self Renewal and Tumorigenicity of Breast Cancer Cells. Cell 2007, 131, 1109-1123. [CrossRef] [PubMed]

49. Singh, S.K.; Clarke, I.D.; Terasaki, M.; Bonn, V.E.; Hawkins, C.; Squire, J.; Dirks, P.B. Identification of a cancer stem cell in human brain tumors. Cancer Res. 2003, 63, 5821-5828.

50. Zhang, S.; Balch, C.; Chan, M.; Lai, H.-C.; Matei, D.; Schilder, J.M.; Yan, P.S.; Huang, T.H.-M.; Nephew, K.P. Identification and Characterization of Ovarian Cancer-Initiating Cells from Primary Human Tumors. Cancer Res. 2008, 68, 4311-4320. [CrossRef]

51. Hagedorn, E.J.; Sherwood, D.R. Cell invasion through basement membrane: The anchor cell breaches the barrier. Curr. Opin. Cell Biol. 2011, 23, 589-596. [CrossRef]

52. Dallas, N.A.; Xia, L.; Fan, F.; Gray, M.J.; Gaur, P.; Van Buren, G.; Samuel, S.; Kim, M.P.; Lim, S.J.; Ellis, L.M. Chemoresistant Colorectal Cancer Cells, the Cancer Stem Cell Phenotype, and Increased Sensitivity to Insulin-like Growth Factor-I Receptor Inhibition. Cancer Res. 2009, 69, 1951-1957. [CrossRef] [PubMed]

53. Choi, E.-H.; Kim, K.P. E2F1 facilitates DNA break repair by localizing to break sites and enhancing the expression of homologous recombination factors. Exp. Mol. Med. 2019, 51, 1-12. [CrossRef] [PubMed]

54. Luoto, K.R.; Meng, A.X.; Wasylishen, A.; Zhao, H.; Coackley, C.L.; Penn, L.; Bristow, R. Tumor Cell Kill by c-MYC Depletion: Role of MYC-Regulated Genes that Control DNA Double-Strand Break Repair. Cancer Res. 2010, 70, 8748-8759. [CrossRef] [PubMed]

55. Hu, J.; Zhang, Z.; Zhao, L.; Li, L.; Zuo, W.; Han, W.Z.A.L. High expression of RAD51 promotes DNA damage repair and survival in KRAS-mutant lung cancer cells. BMB Rep. 2019, 52, 151-156. [CrossRef] [PubMed]

56. Yang, S.; Chintapalli, J.; Sodagum, L.; Baskin, S.; Malhotra, A.; Reiss, K.; Meggs, L.G. Activated IGF-1R inhibits hyperglycemiainduced DNA damage and promotes DNA repair by homologous recombination. Am. J. Physiol. Physiol. 2005, 289, F1144-F1152. [CrossRef]

57. Lee, Y.S.; Dutta, A. The tumor suppressor microRNA let-7 represses the HMGA2 oncogene. Genes Dev. 2007, 21, 1025-1030. [CrossRef] [PubMed]

58. Madison, B.B.; Jeganathan, A.N.; Mizuno, R.; Winslow, M.M.; Castells, A.; Cuatrecasas, M.; Rustgi, A.K. Let-7 Represses Carcinogenesis and a Stem Cell Phenotype in the Intestine via Regulation of Hmga2. PLoS Genet. 2015, 11, e1005408. [CrossRef]

59. Bapat, S.A.; Mali, A.M.; Koppikar, C.B.; Kurrey, N. Stem and Progenitor-Like Cells Contribute to the Aggressive Behavior of Human Epithelial Ovarian Cancer. Cancer Res. 2005, 65, 3025-3029. [CrossRef]

60. Park, H.; Hwang, S.; Jeong, J.-Y.; Jung, S.G.; Choi, M.C.; Joo, W.D.; Song, S.H.; Lee, C.; An, H.J. Integrative analysis of transcription factors and microRNAs in ovarian cancer cell spheroids. J. Ovarian Res. 2020, 13, 1-10. [CrossRef]

61. Gao, Q.; Yang, Z.; Xu, S.; Li, X.; Yang, X.; Jin, P.; Liu, Y.; Zhou, X.; Zhang, T.; Gong, C.; et al. Heterotypic CAF-tumor spheroids promote early peritoneal metastasis of ovarian cancer. J. Exp. Med. 2019, 216, 688-703. [CrossRef]

62. Zong, X.; Wang, W.; Ozes, A.; Fang, F.; Sandusky, G.E.; Nephew, K.P. EZH2-Mediated Downregulation of the Tumor Suppressor DAB2IP Maintains Ovarian Cancer Stem Cells. Cancer Res. 2020, 80, 4371-4385. [CrossRef] [PubMed]

63. Ogishima, J.; Taguchi, A.; Kawata, A.; Kawana, K.; Yoshida, M.; Yoshimatsu, Y.; Sato, M.; Nakamura, H.; Kawata, Y.; Nishijima, A.; et al. The oncogene KRAS promotes cancer cell dissemination by stabilizing spheroid formation via the MEK pathway. BMC Cancer 2018, 18, 1201. [CrossRef]

64. Chaffer, C.L.; Weinberg, R.A. A Perspective on Cancer Cell Metastasis. Science 2011, 331, 1559-1564. [CrossRef] [PubMed]

65. Dudjak, L.A. Cancer metastasis. Semin. Oncol. Nurs. 1992, 8, 40-50. [CrossRef]

66. Li, Y.; Zhang, X.; Chen, D.; Ma, C. Let-7a suppresses glioma cell proliferation and invasion through TGF- $\beta$ /Smad3 signaling pathway by targeting HMGA2. Tumor Biol. 2015, 37, 8107-8119. [CrossRef]

67. Zhang, Z.; Li, Y.; Huang, L.; Xiao, Q.; Chen, X.; Zhong, J.; Chen, Y.; Yang, D.; Han, Z.; Shu, Y.; et al. Let-7a suppresses macrophage infiltrations and malignant phenotype of Ewing sarcoma via STAT3/NF-kB positive regulatory circuit. Cancer Lett. 2016, 374, 192-201. [CrossRef]

68. Tang, R.; Yang, C.; Ma, X.; Wang, Y.; Luo, D.; Huang, C.; Xu, Z.; Liu, P.; Yang, L. MiR-let-7a inhibits cell proliferation, migration, and invasion by down-regulating PKM2 in gastric cancer. Oncotarget 2016, 7, 5972-5984. [CrossRef]

69. Xu, X.; Bao, Z.; Liu, Y.; Ji, J.; Liu, N. MicroRNA-98 Attenuates Cell Migration and Invasion in Glioma by Directly Targeting Pre-B Cell Leukemia Homeobox 3. Cell. Mol. Neurobiol. 2017, 37, 1359-1371. [CrossRef] [PubMed]

70. Zhao, B.; Han, H.; Chen, J.; Zhang, Z.; Li, S.; Fang, F.; Zheng, Q.; Ma, Y.; Zhang, J.; Wu, N.; et al. MicroRNA let-7c inhibits migration and invasion of human non-small cell lung cancer by targeting ITGB3 and MAP4K3. Cancer Lett. 2014, 342, 43-51. [CrossRef]

71. Johnson, S.M.; Grosshans, H.; Shingara, J.; Byrom, M.; Jarvis, R.; Cheng, A.; Labourier, E.; Reinert, K.L.; Brown, D.; Slack, F.J. RAS Is Regulated by the let-7 MicroRNA Family. Cell 2005, 120, 635-647. [CrossRef] 
72. The Cancer Genome Atlas Research Network Integrated genomic analyses of ovarian carcinoma. Nature 2011, 474, 609-615. [CrossRef]

73. Hira, M.T.; Razzaque, M.A.; Angione, C.; Scrivens, J.; Sawan, S.; Sarker, M. Integrated multi-omics analysis of ovarian cancer using variational autoencoders. Sci. Rep. 2021, 11, 1-16. [CrossRef]

74. Zhang, H.; Liu, T.; Zhang, Z.; Payne, S.; Zhang, B.; McDermott, J.; Zhou, J.-Y.; Petyuk, V.A.; Chen, L.; Ray, D.; et al. Integrated Proteogenomic Characterization of Human High-Grade Serous Ovarian Cancer. Cell 2016, 166, 755-765. [CrossRef]

75. Matulonis, U.; Shapira-Frommer, R.; Santin, A.; Lisyanskaya, A.; Pignata, S.; Vergote, I.; Raspagliesi, F.; Sonke, G.; Birrer, M.; Provencher, D.; et al. Antitumor activity and safety of pembrolizumab in patients with advanced recurrent ovarian cancer: Results from the phase II KEYNOTE-100 study. Ann. Oncol. 2019, 30, 1080-1087. [CrossRef] [PubMed]

76. Marabelle, A.; Fakih, M.; Lopez, J.; Shah, M.; Shapira-Frommer, R.; Nakagawa, K.; Chung, H.C.; Kindler, H.L.; Lopez-Martin, J.A.; Miller, W.H.; et al. Association of tumour mutational burden with outcomes in patients with advanced solid tumours treated with pembrolizumab: Prospective biomarker analysis of the multicohort, open-label, phase 2 KEYNOTE-158 study. Lancet Oncol. 2020, 21, 1353-1365. [CrossRef]

77. Khella, C.; Mehta, G.; Mehta, R.; Gatza, M. Recent Advances in Integrative Multi-Omics Research in Breast and Ovarian Cancer. J. Pers. Med. 2021, 11, 149. [CrossRef] [PubMed]

78. Lu, T.; Bankhead, A.; Ljungman, M.; Neamati, N. Multi-omics profiling reveals key signaling pathways in ovarian cancer controlled by STAT3. Theranostics 2019, 9, 5478-5496. [CrossRef]

79. Liu, X.; Ory, V.; Chapman, S.; Yuan, H.; Albanese, C.; Kallakury, B.; Timofeeva, O.A.; Nealon, C.; Dakic, A.; Simic, V.; et al. ROCK Inhibitor and Feeder Cells Induce the Conditional Reprogramming of Epithelial Cells. Am. J. Pathol. 2012, 180, $599-607$. [CrossRef]

80. Edelstein, A.D.; Amodaj, N.; Hoover, K.H.; Vale, R.D.; Stuurman, N. Computer Control of Microscopes Using $\mu$ Manager. Curr. Protoc. Mol. Biol. 2010, 92, 14.20.1-14.20.17. [CrossRef]

81. Moutasim, K.A.; Nystrom, M.L.; Thomas, G.J. Cell Migration and Invasion Assays. J. Vis. Exp. 2011, 731, 333-343. [CrossRef] 